Review

\title{
The Soil Degradation Paradox: Compromising Our Resources When We Need Them the Most
}

\section{Catherine DeLong ${ }^{1, *}$, Richard Cruse ${ }^{1, \dagger}$ and John Wiener ${ }^{2, \dagger}$}

1 Department of Agronomy, Iowa State University, Ames, IA 50011, USA; E-Mail: rmc@iastate.edu

2 Institute of Behavioral Science, University of Colorado, 468 UCB, Boulder, CO 80309-0468, USA; E-Mail: john.wiener@colorado.edu

$\dagger$ These authors contributed equally to this work.

* Author to whom correspondence should be addressed; E-Mail: crdelong@iastate.edu; Tel.: +1-515-294-7850; Fax: +1-515-294-3163.

Academic Editor: Douglas L. Karlen

Received: 19 November 2014 / Accepted: 7 January 2015 / Published: 13 January 2015

\begin{abstract}
Soil degradation can take many forms, from erosion to salinization to the overall depletion of organic matter. The expression of soil degradation is broad, and so too are the causes. As the world population nears eight billion, and the environmental uncertainty of climate change becomes more manifest, the importance of our soil resources will only increase. The goal of this paper is to synthesize the catalysts of soil degradation and to highlight the interconnected nature of the social and economic causes of soil degradation. An expected three billion people will enter the middle class in the next 20 years; this will lead to an increased demand for meat, dairy products, and consequently grain. As populations rise so do the economic incentives to convert farmland to other purposes. With the intensity and frequency of droughts and flooding increasing, consumer confidence and the ability of crops to reach yield goals are also threatened. In a time of uncertainty, conservation measures are often the first to be sacrificed. In short, we are compromising our soil resources when we need them the most.
\end{abstract}

Keywords: soil erosion; salinization; land degradation; soil degradation; climate change 


\section{Introduction}

The year 2015 has been declared the International Year of Soils by the United Nations (UN). The goal is to raise global awareness of the importance of soil for food security, climate adaptability and ecosystem functioning. Inspired by the UN's declaration, this paper serves to acknowledge the vital role that soil plays in our ecosystem, with particular emphasis on the increasingly significant role that degraded soils will play as the global population rises, and resources are stressed by climate instability [1]. The first section addresses the importance of preserving our soil resources as agricultural demand is amplified by shifting dietary expectations and an overall increase in earth's population. As agricultural demand increases, more output will be required of our soil resources, which in turn may increase the rate of soil degradation. Considering that $25 \%$ of agricultural land is already highly degraded, research addressing the ability of our land resources to meet agricultural demand on increasingly degraded soils is an area of study that demands attention [2]. The second section places this increased agricultural demand in the context of climate instability and the resultant, and already occurring, strain on our natural resources. Often, when uncertainty is looming, such as a fluctuating climate and an unclear ability to meet demand, soil conservation measures are the first to be sacrificed in order to reach yield goals. However, this near-sighted approach compromises our soil resources when we need them the most. The soil plays a critical role in buffering against climate extremes, and yet the role of degraded soils in climate models remains poorly studied. The goal of this paper is to bring into focus the increasingly important role that our soil resources, and particularly degraded soils, will play in the future. As more output is demanded of our soil, and climate volatility compromises the ability to meet this demand, maintaining healthy soils will only become more difficult, but more necessary.

\section{Soil Degradation: A Global Pandemic}

The expression of soil degradation is varied, but as the other papers in the journal demonstrate, it is extensive. Soil degradation is not isolated to one region, or even one continent; it is a world problem. Eleven percent of the earth's land surface is occupied by agriculture and $25 \%$ is already highly degraded according to the UN's Food and Agriculture Organization [2]. Although the expressions of soil degradation range from salinization to the overall depletion of organic matter and nutrients, perhaps the two most extensive forms are salinization and erosion.

Salinization, or the buildup of salts in soil, decreases the osmotic potential of soils so that plants are unable to take up sufficient water to meet physiological needs. Additionally, reclaiming saline soils usually requires large amounts of irrigation water which, as will be discussed later, is a limiting resource in many regions. Salinization is an ancient problem; the birthplaces of agriculture, Mesopotamia and other parts of the Fertile Crescent, were degraded by salinization to the point of abandonment. Today, 34 million ha of land are affected by salinization and some of the major hotspots are in the United States, Pakistan, Iraq and China [2]. Wood [3] estimates that, globally and at varying degrees, salinity will affect an additional 1.5 million ha of arable land each year.

Erosion is the dominant form of soil degradation [4,5]. Erosion removes the most nutrient rich and organic matter dense layer of a soil profile. In turn, this can compromise soil fertility, structure and available water holding capacity. The reach of soil erosion is global and the rate at which it is occurring 
is often unsustainable. In Europe, Verheijen [6] found that on tilled, arable land, soil is eroding, on average, at 3-40 times the upper tolerable rate of $1.4 \mathrm{t} / \mathrm{ha}$ annually. In sub-Saharan Africa, Vlek [7] found that $70 \%$ of farmland is degraded due to erosion. In the United States, a meta-analysis by Pimental [8] reports that soil is eroding ten times faster than regeneration rates, while in China and India the rates are 30-40 times faster than regeneration rates. Globally, Montgomery [9] estimates that conventional agriculture practices result in erosion rates that are one to two orders of magnitude greater than both the erosion rate under natural vegetation and soil regeneration rates. In layman terms, we are losing soil much faster than we can replace it.

Additionally, the majority of water-induced soil erosion estimates do not include soil lost from ephemeral gullies, or the cuts in the land that form seasonally [10]. This means that while our estimated and reported soil erosion rates have, in many cases, already reached unsustainable levels, the reported values are potentially much lower than what is actually happening on the ground. Estimated soil erosion rates normally include only sheet and rill erosion components, and are typically reported as averages over relatively large geographical areas, such as reported periodically by the United Stated Department of Agriculture in the National Resources Inventory (NRI) [10]. The NRI uses a stratified statistical sampling methodology allowing definable confidence levels to be identified regarding soil erosion estimates for each state in the United States. The NRI is a critically important and reliable resource, however, it does not illustrate soil erosion rates occurring at spatial scales that account for topographical features, management decisions, and variable rainfall.

To illustrate, as shown in Figure 1, in 2011 the Environmental Working Group utilized the Iowa Daily Erosion Project [11] to identify estimated soil erosion rates for each township in Iowa for 2007 and contrasted results to those of the NRI statewide average for that same year [12]. For the state, NRI erosion estimates were 11.6 Mg/ha for 2007, while the Iowa Daily Erosion Project estimated that at the township level more than 2.4 million ha, or close to $17 \%$ of the state, was eroding at rates greater than $22 \mathrm{Mg} / \mathrm{ha}$. The maximum estimated township erosion rates were over $130 \mathrm{Mg} / \mathrm{ha}$ in 2007 . Further, estimates at the township level, approximately $100 \mathrm{~km}^{2}$, are still too coarse to adequately express the intense spatial variability of soil erosion at the field scale. Current erosion estimates, averages at large spatial scales, therefore inadvertently conceal the damage to critical crop production areas and give a false sense of security on the impacts to crop production.

As the Food and Agriculture Organization reported, soil degradation is not a theoretical problem; it is actively diminishing production capacity and compromising livelihoods at this very moment [2]. Giller [13] found that on experiments in Zimbabwe, degraded soils were less likely to respond to fertilizers because of deficiencies of Ca, Zn, N and P. In Ghana, Diao [14] asserts that land degradation associated with soil erosion will reduce agricultural income from 2006 to 2015 by approximately $\$ 4.2$ billion or $5 \%$ of agriculture's gross domestic product. Due to erosion, yields have been compromised by $20 \%$ in India, China, Iran, Israel, Jordan, Lebanon and Pakistan [15]. Globally, salinity has the potential to decrease production at a cost of $\$ 11$ billion per year [3]. And lastly, Pimentel [8] found that soil erosion costs the US $\$ 37.6$ billion each year in productivity losses, while worldwide the estimate is close to $\$ 400$ billion annually.

Soil degradation, however, is not an inevitable result of agriculture; while $25 \%$ of cultivated land is highly degraded, $10 \%$ is improving [2]. The need to maintain and improve our soil resources will only become more essential as demand for agricultural products increase, and land and water resources 
diminish. Ironically, rising agricultural demand and resource stress are increasing reliance on our soil resources while also driving soil degradation. The next sections of this paper will explore some of the socio-economic and environmental factors that drive soil degradation.

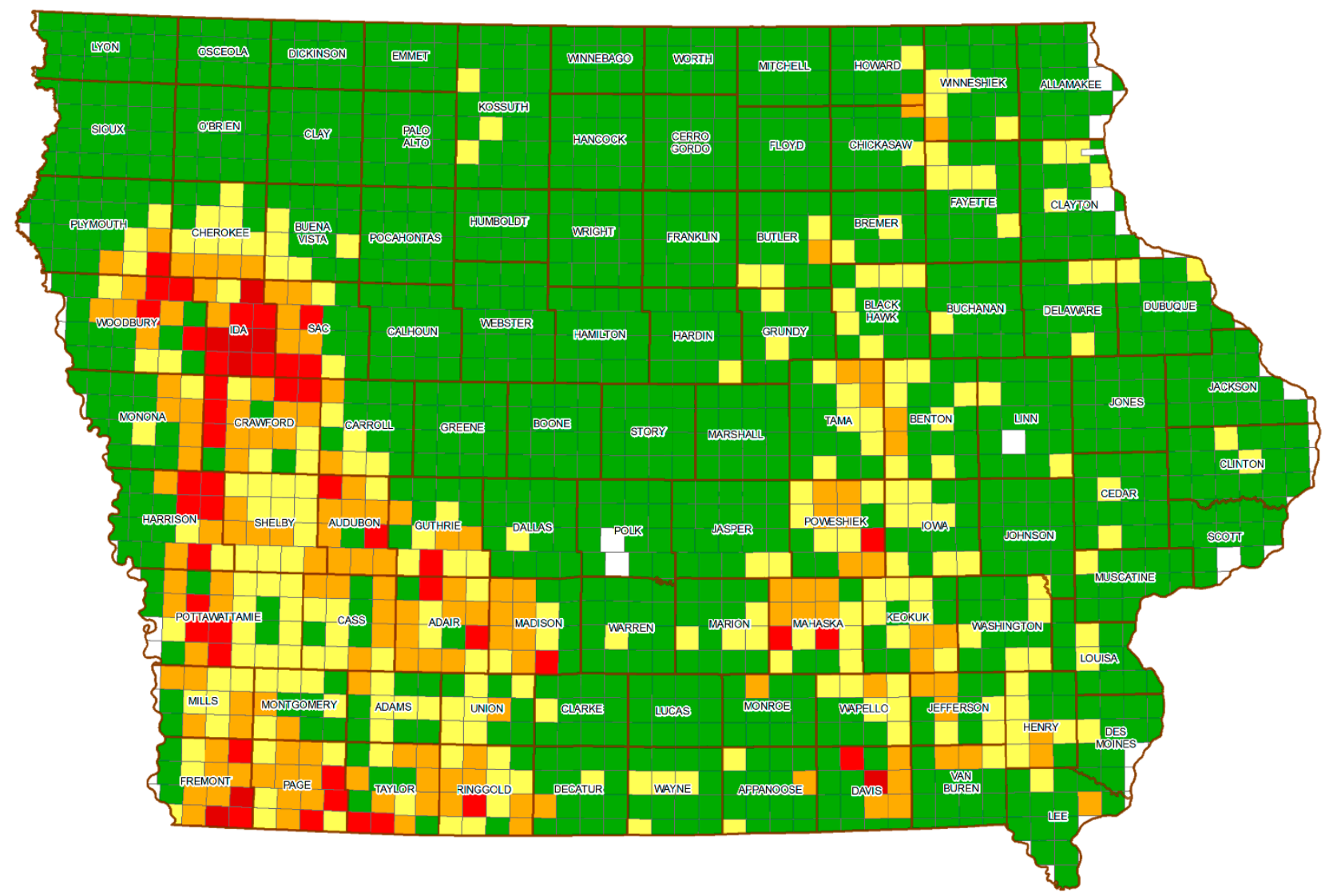

Average Soil Erosion (Mg/Ha)

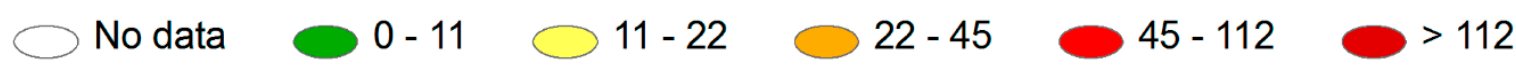

Figure 1. Average estimated sheet and rill soil erosion rates for each township in Iowa for 2007 [12].

\section{Increased Demand for Agricultural Products: Rising Populations and Shifting Class Lines}

In the next 40 years, it is predicted that the world population of 7.1 billion will swell by $35 \%$ [16]. This growing population will result in an increased demand for agricultural products, and intensifying demands on cropland. One-third of the food produced for human consumption is currently wasted every year, and unless there are drastic improvements in the supply chain and individuals' lifestyles, this trend will remain a constant, and any increase in population will require an increase in calories produced [17]. Not only is the population as a whole rising, but socio-economic shifts within the population are leading to an increased demand for meat and dairy products, and further demand on grain production.

Three billion people are expected to enter the middle class in the next 20 years [17], and as pointed out by Conway [18], growth in domestic product increases in unison with meat demand. What does this increased meat consumption mean for land and water resources? We will assume that the average "new" middle class will consume $\sim 0.19 \mathrm{~kg} /$ capita/day of meat, or $60 \%$ of the average daily meat consumption of a US citizen [19]. Meat consumption in developing countries currently averages 
$0.09 \mathrm{~kg} / \mathrm{capita} /$ day [20]. If three billion people are added to the middle class and meat consumption increases from $0.09 \mathrm{~kg} /$ capita/day to $0.19 \mathrm{~kg} /$ capita/day, this means an additional 300 million $\mathrm{kg}$ of meat must be produced daily. Assuming a $25 \%$ average protein content for meat, 75 million $\mathrm{kg}$ of animal protein must be produced daily to meet this need [21].

In turn, animals must consume $100-2200 \mathrm{~kg}$ of dry matter in order to produce one $\mathrm{kg}$ of protein. The conversion efficiency depends on the species of animal, environment, and quality of dry matter being fed [21]. If we assume the most efficient conversion (100 kg dry matter intake per $1 \mathrm{~kg}$ protein produced), our land and water resources must produce an additional 7.5 billion $\mathrm{kg}$ of dry matter daily. Herrero [21] indicates that the daily global dry matter consumption by livestock in 2000 was approximately 12.9 billion $\mathrm{kg}$. The implication for greater feed production per unit of land area and/or expansion of land area for animal feed production is nontrivial. Currently, livestock production accounts for $23 \%$ of all agricultural water use; growth in animal production to meet this rising demand will significantly amplify water demand beyond the strain we are currently experiencing [20].

Further heightening the pressure on land resources is increased biofuel production. In the United States, ethanol, a corn-based biofuel, consumes $25 \%$ of the annual maize harvest [22]. From 2000 to 2013, this was an increase of almost $720 \%$ [23], with the amount of land dedicated to biofuel production increasing by $10 \%$ during the same period [24]. This statistic also takes into account that one-third of the calories used in ethanol production can be recycled for animal feed [25]. In Europe, by 2020 European Union Member States have predicted an increase of 4.1-6.9 million ha of land use changes associated with biofuels [26]. Although estimates for the amount of crops and land dedicated to biofuel use are varied, most studies are in agreement that the number is increasing [27-29]. Additionally, the rising number of hectares that are used for biofuels is not at the expense of uncultivated land, but rather land that is already dedicated to food or feed crops [24]. Thus, the soil is likely to be used more intensely as food production competes with fuel production on finite, and decreasing, land resources.

In the past, a Malthusian catastrophe was avoided by improved plant varieties, and increased fertilizer and irrigated water use associated with the Green Revolution [30]. However the innovations of the Green Revolution may be reaching important plateaus [27,31]. During the Green Revolution productivity growth was at $\sim 2 \%$ per year, while today it has declined to $\sim 1 \%$ [32]. Yield plateaus have been observed in rice in the Republic of Korea, and wheat in northwest Europe, and India. Additionally, production plateaus have been witnessed for rice and maize in China, which is currently the largest producer of these crops [33]. Despite attempts to make "drought resistant" crops, yield gains will always be tied to the availability of water sources and a fundamental principle of plant physiology that nutrients can only be taken up by the plant in solution. Sinclair [34] clearly articulates that continued crop yield increases are not likely since yield is coupled to transpiration, and a plant cannot continually and exponentially increase its water uptake. Evidence is also mounting that past yield gains have come at the cost of nutritional content as well as the crops' ability to respond to environmental stresses such as drought [35,36]. Thus a higher quantity of crops may be needed to meet the nutritional needs of a single person while the population as a whole is rising.

Further threatening food production is the reality that agricultural land is rapidly being converted to other uses for economic gain. Lambin [37] predict that urbanization will remove 1.6-3.3 Mha of prime agricultural land from production every year. In Bangladesh, land is being converted at an annual rate of $0.56 \%$, resulting in a loss of rice production of $0.86 \%-1.16 \%$ annually [38]. Land use plans in 
Indonesia have called for as much as $42 \%$ of their high-producing rice paddy fields to be converted to other uses [39]. Rice is a major food source for over half of the world's population, and Bangladesh and Indonesia are the third and fourth highest suppliers of rice after China and India [40]. In the United States, over 9.3 million ha of agricultural land were converted to nonagricultural uses from 1982 to 2007, or about $2.5 \%$ of farmland [41]. As agricultural land is lost to urbanization, often ignored is the additional cost to our soil resources; globally 1.0-2.9 million ha of soil are degraded annually as a result of expanding cities [37]. Agricultural land area is decreasing and likely to be used more intensely due to the successive forces of rising populations, expanding cities and soil degradation. But in order to provide for the growing population on fewer hectares, we must first preserve our current soil resources. Here is yet another example of the paired fate of increased calories and soil resources; the former cannot be accomplished without maintaining the latter.

With rising food demand and a marginal ability to meet this demand due to soil degradation and land conversion, we are increasingly susceptible to production shocks and ensuing volatile food prices [42]. These "shocks" pose a significant threat to our soil resources as price volatility leads to conservation measures being undervalued and often abandoned. Generally, gross food prices have fallen over the past century and stabilized in the past three decades, but these trends have recently been interrupted by spikes in food prices [43]. Food prices, an indicator of global food availability, have been implicated as a harbinger of political unrest. Lagi [44] point out that in 2008, food riots occurred in 30 countries in North Africa and the Middle East which were experiencing high food prices. In early 2010 and late 2011, even higher food prices corresponded with riots in Mauritania, Uganda and other countries associated with the Arab Spring [44]. The root cause of these spikes in food prices is still being debated, although most researchers agree that resource competition due to biofuel production is a factor $[45,46]$. One thing is certain, as the demand for agricultural products increases due to rising biofuel production, growing populations and the improved economic status of billions, more will be asked of our land resources. Healthy soils will be necessary to meet these rising demands and avoid the political unrest that often accompanies food price volatility.

\section{Resource Stress: Climate Change and Our Soil Resources}

In 2013 the concentration of greenhouse gases in our atmosphere outpaced predictions and reached historically high levels [47]. As the concentration of these heat-trapping gases has increased, so too have global temperatures. According to the International Panel on Climate Change (IPCC), the period from 1983 to 2012 was the warmest three decades in the past 1400 years [29]. Needless to say, the effects of climate change are not likely to decrease in the near future. And with each degree of warming, the environmental repercussions are neither incremental nor linear, but exponential [29,48,49]. Impacts include volatile and increasingly intense precipitation events, lengthier droughts, sea level rise and decreasing water resources [29]. However, climate models that forecast these events rarely include the limitation of highly degraded soils in their interaction studies. The next section will detail the resource stress that is likely with climate change. It serves to highlight the importance of maintaining our soil resources as a buffer against climate extremes as well as critical to reaching yield goals.

The majority of crop models predict that global crop yields are declining and will continue to decline as a result of climate change [29,42,50,51]. Lobell [52] found that from 1980 to 2010, the warmest three 
decades in the past 1400 years, global maize harvest was reduced by $3.8 \%$ while wheat was reduced by $5.5 \%$. Although there are significant regional differences in the effect of climate change on crop yields, there is particular consensus that yield losses will occur at low latitudes and tropical areas [29]. These are often the areas, as Wheeler [53] points out, where individuals are already suffering from hunger [30]. More positively, many researchers agree that increased temperatures will have a positive effect on production potential at higher latitudes, although the accompanying soil limitations at these latitudes are rarely addressed [49,50]. In fact, the most recent IPCC Report notes that scientific publications assessing climate impacts, adaptation and vulnerability have "more than doubled" between 2005 and 2010, while studies that address the intersection of climate change and soil resources, particularly the increasing prevalence of degraded soils, are minimal [28,29].

Rising atmospheric $\mathrm{CO}_{2}$ levels result in warmer air which is able to hold a higher water vapor content. As the global hydrologic cycle intensifies so too will precipitation extremes such as extended wet and dry periods [29]. It is predicted that dry areas, such as sub-tropical regions, will become drier, and wet equatorial regions, will become wetter [54-56]. The productivity of agricultural systems is likely to be limited by environmental extremes rather than averages. For instance, plant response to extended periods of drought will be more important than gradual and incremental changes in precipitation averages. Just as the response of degraded soils is rarely addressed in climate change studies, research addressing crop response to variance in climate change, such as extended wet or dry periods, is needed.

Higher energy storm potentials and extreme precipitation events are also being observed and predicted as a result of increased energy being stored in the atmosphere as latent heat $[29,57]$. According to Nearing [58], as precipitation increases, soil erosion increases by a factor of 1.7, thus heightening the vulnerability of soil under future climate scenarios. A healthy soil, with high organic matter, can help buffer against precipitation extremes through increased aggregation which allows for higher infiltration and increased water and nutrient retention [59]. Soil productivity of vast areas has been reduced, and in some areas totally lost, due to soil degradation associated with erosion; a climate with an increasing frequency of extreme rainfall events will likely accelerate this process.

In order to understand the potential impact of precipitation and temperature fluctuations, we will take a closer look at the European continent. Fischer [60], using terrain suitability and current rainfall patterns, identified a broad band across Europe as having a high, relative, suitability for rain-fed agriculture. This observation is not surprising considering that central Europe has a high concentration of organic matter rich Mollisols [61]. However, as Figure 2 shows, the IPCC has pinpointed a similar band across Europe as being likely to experience a decrease in summer rainfall of more than $20 \%$ in the coming decades [62]. While growing seasonal rainfall is predicted to decrease, Figure 3 demonstrates that temperatures over the European land surface have rapidly increased since the mid to late 1980s [63] causing hotter and drier summer conditions, and an increased likelihood for crop stress. And perhaps the greatest threat to production potential, and in particular rain-fed crop potential, is the alarming rate of soil degradation in this region identified by Verheijen [6]. These analyses for the European continent serve to highlight two facts. First, we cannot properly address the risks and impacts of climate change without including soil degradation as a limiting factor. And, resource stress, such as precipitation declines, means modelers and land managers alike need to value the role that healthy soils play in buffering against climate extremes. 


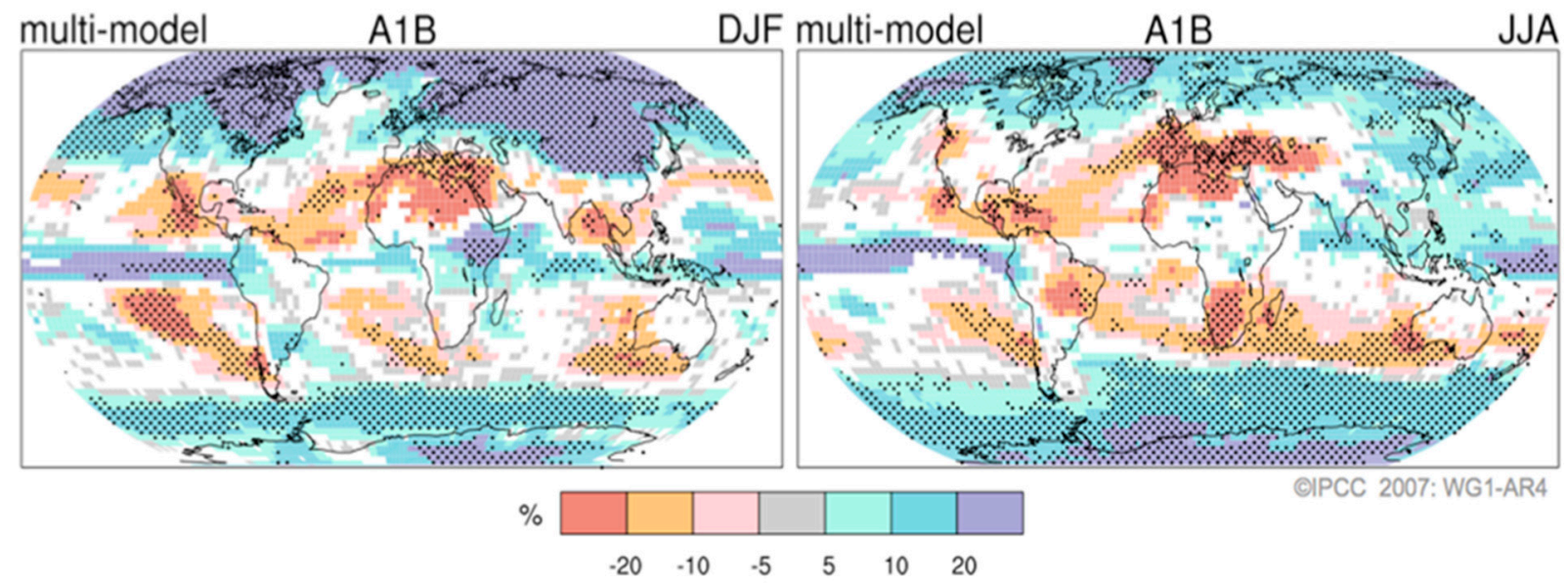

Figure 2. Projected patterns of precipitation change across the globe for the 21 st century. Left side projects for the months of December, January and February. Right side projects changes for the months of June, July, and August [62].
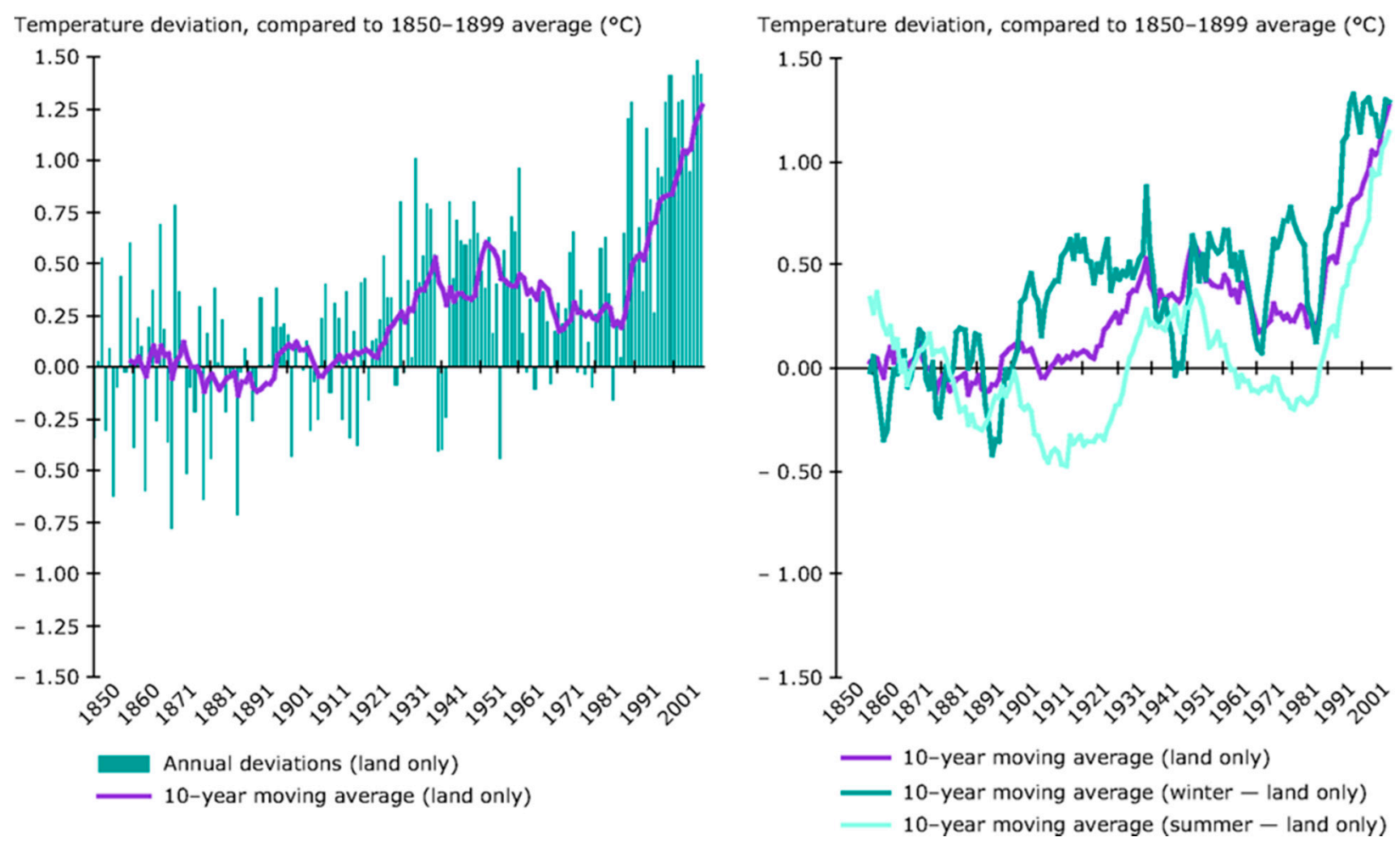

Figure 3. For the period 1850-2009, observed annual temperature $\left(\mathrm{C}^{\circ}\right)$ deviations from the 1850-1899 average, and 10-year average for the same period over the European land surface (left). For the period 1850-2009, observed 10-year average temperature $\left(\mathrm{C}^{\circ}\right)$ deviations from the 1850-1899 average for the European land surface (right) [63].

Through variable and extreme temperature and precipitation events, like those seen in Europe, climate change is likely to cause resource stress and crop yield fluctuations. As the global population rises and class lines shift, there is also high certainty that demand for agriculture products will increase. The combination of these two pressures, unstable crop yields and fluctuating populations, is likely to lead land managers to rely heavily on irrigation to stabilize their crop yields. Already, modern agriculture and 
irrigation are tightly linked. The UN's Food and Agriculture Organization states that $20 \%$ of agricultural land is irrigated, and this land provides $40 \%$ of the world's food supply [64]. Irrigated land produces yields that are, on average, two to three times higher than rain-fed land in developing countries [65]. Agriculture relies on the weather, an inherently risky position, but irrigation reduces the risk and allows higher and more stable crop yields and a more predictable income for the farmer.

However, our freshwater resources are finite, and nowhere is this better illustrated than in our depleted groundwater supplies. The High Plains Aquifer in the central United States is one of the world's largest freshwater aquifers and the main source of irrigation and drinking water for the eight states that overlie it. Unsustainable pumping of the aquifer has resulted in water level declines of greater than $45 \mathrm{~m}$ in parts of Texas, New Mexico and Kansas [66]. In northern China, where the majority of the country's cereals, cotton, fruits and vegetables are grown, groundwater levels have declined at the rate of 0.5 to $3 \mathrm{~m}$ annually in the last three decades [67]. Saudi Arabia, in the past, used irrigated aquifer water for domestic wheat production, but today the vast majority of wheat is imported because of depleted groundwater supplies that were increasingly difficult to reach [68]. Globally, Konikow [69] estimates that groundwater has been depleted by approximately $4500 \mathrm{~km}^{3}$ between 1900 and 2008, with the highest rate of depletion in the last decade. Providing for a growing population with less water for crop production seems a stark reality, and one that will most likely require increased dependence on healthy soils and rain-fed agriculture.

\section{Conclusions}

Climate scientists are in agreement that the foreseeable future holds a higher propensity for extreme weather events, and an overall, and growing, strain on earth's resources. The main conclusion, however, is that our climate is changing and our future is increasingly uncertain. Adding to this uncertainty is the lack of inclusion given to soil, and particularly degraded soils, in climate models. Perhaps this is because soil is viewed as static, but it is more likely that studying the impact of multiple and interconnected stressors on our environment is a difficult venture. However, this is the future of our food production system, and soil degradation must be recognized as playing a dominant role or projections will not adequately represent our future.

Accelerated soil degradation is likely with increasing precipitation intensity and frequency, limiting water resources, and an increased demand for agricultural products from a growing population. Degradation is likely to accelerate as land managers respond to climate variability and increased demand by abandoning long-term soil conservation measures in order to insure yield goals for the current year. Here is the soil degradation paradox: climate variability and a growing population directly and indirectly lead to soil degradation just as healthy soils are increasingly needed to buffer against climate extremes and provide for the population.

Just as the causes of soil degradation are varied and interconnected, the solutions require cooperation, innovation and communication across many groups. The first step is for the scientific community to recognize the societal value of soil and to include it in their discussions, studies and models. In order to accomplish this, soil scientists must be included in trans-disciplinary studies, and soil scientists themselves must broaden their focus and publish their results in a language that is accessible to others. While $25 \%$ of agricultural land is highly degraded, $10 \%$ is improving [2]. Soil degradation is not an 
inevitability of agriculture; on the contrary, agriculture can and has improved degraded land by rehabilitating saline soils and implementing conservation measures. By being cognizant of the drivers of soil degradation and recognizing the soils critical role in providing for a growing planet and buffering against climate change, we can avoid the soil degradation paradox.

\section{Author Contributions}

Catherine DeLong was the lead author. She drafted sections and integrated sections supplied by Richard Cruse and John Wiener into the final draft. Richard Cruse was responsible for the paper topic area and focus; he also assisted in writing and editing. John Wiener supplied reference and writing support. All authors have read and approved the final manuscript.

\section{Conflicts of Interest}

The authors declare no conflict of interest.

\section{References}

1. Karlen, D.L.; Peterson, G.A.; Westfall, D.G. Soil and conservation: Our history and future challenges. Soil Sci. Soc. Am. J. 2014, 78, 1493-1499.

2. Food and Agriculture Organization of the United Nations (FAO). The State of the World's Land and Water Resources for Food and Agriculture (SOLAW)_Managing Systems at Risk; Earthscan: New York, NY, UK, 2011.

3. Wood, S.; Sebastian, K.; Scherr, S.J. Pilot Analysis of Global Ecosystems: Agroecosystems; International Food Policy and Research Institute \& World Resources Institute: Washington, DC, USA, 2000.

4. Troeh, F.R.; Hobbs, J.A.; Donahue, R.L. Soil and Water Conservation; Prentice Hall: Englewood Cliffs, NJ, USA, 1991.

5. Oldeman, L.R. Soil degradation: A threat to food security? In Proceedings of the International Conference on Time Ecology: Time for Soil Culture-Temporal Perspectives on Sustainable Use of Soil, Tutzing, Germany, 6-9 April 1997.

6. Verheijen, F.G.A.; Jones, R.J.A.; Rickson, R.J.; Smith, C.J. Tolerable versus actual soil erosion rates in Europe. Earth Sci. Rev. 2009, 94, 23-38.

7. Vlek, P.; Le, Q.B.; Tamene, L. Land Decline in Land-Rich AFRICA-A Creeping Disaster in the Making; CGIAR Science Council Secretariat: Rome, Italy, 2008.

8. Pimentel, D. Soil erosion: A food and environmental threat. Environ. Dev. Sustain. 2006, 8, 119-137.

9. Montgomery, D. Soil erosion and agricultural stability. Proc. Natl. Acad. Sci. USA 2007, 104, 13268-13272.

10. USDA. Summary Report: 2010 National Resources Inventory. Available online: http://www.nrcs.usda.gov/Internet/FSE_DOCUMENTS/stelprdb1167354.pdf (accessed on 12 January 2015). 
11. Cruse, R.M.; Flanagan, D.; Frankenberger, J.; Gelder, J.; Herzmann, D.; James, D.; Krajewski, W.; Kraszewski, M.; Laflen, J.; Opsomer, J.; et al. Daily estimates of rainfall, water runoff, and soil erosion in Iowa. J. Soil Water Conserv. 2006, 61, 191-199.

12. Cox, C.; Hug, A.; Bruzelius, N. Losing Ground; Environmental Working Group: Ames, IA, USA, 2011.

13. Giller, K.E.; Tittonell, P.; Rufino, M.C.; van Wijk, M.T.; Zingore, S.; Mapfumo, P.; Adjei-Nsiah, S.; Herrero, M.; Chikowo, R.; Corbeels, M.; et al. Communicating complexity: Integrated assessment of trade-offs concerning soil fertility management within African farming systems to support innovation and development. Agric. Syst. 2011, 104, 191-203.

14. Diao, X.; Sarpong, D.B. Cost Implications of Agricultural Land Degradation in Ghana: An Economy-Wide, Multimarket Model Assessment; International Food Policy Research Institute: Washington, DC, USA, 2007.

15. Dregne, H.E., Ed. Degradation and Restoration of Arid Lands; Texas Technical University: Lubbock, TX, USA, 1992.

16. Department of Economic and Social Affairs, Population Division, United Nations. World Population Prospects: The 2010 Revision, Volume I: Comprehensive Tables; ST/ESA/SER.A/313; United Nations: New York, NY, USA, 2011.

17. United Nations Secretary-General's High-Level Panel on Global Sustainability. Resilient People, Resilient Planet: A future Worth Choosing; United Nations: New York, NY, USA, 2012.

18. Conway, G. One Billion Hungry: Can We Feed the World? Cornell University Press: New York, NY, USA, 2012; p. 192.

19. FAOstat. Available online: http://faostat.fao.org/site/610/DesktopDefault.aspx?PageID=610\#ancor (accessed on 14 October 2014).

20. World Watch Institute. Available online: http://www.worldwatch.org/global-meat-production-andconsumption-continue-rise (accessed 14 October 2014).

21. Herrero, M.; Havlik, P.; Valin, H.; Notenbaert, A.; Rufino, M.C.; Thornton, P.K.; Blummel, M.; Weiss, F.; Grace, D.; Obersteiner, M. Biomass use, production, feed efficiencies, and greenhouse gas emissions from global livestock systems. Proc. Natl. Acad. Sci. USA 2013, 110, 20888-20893.

22. USDA. Table 5. Corn Supply, Disappearance, and Share of Total Corn Used for Ethanol; US Department of Agriculture Economic Research Service, US Bioenergy Statistics: Washington, DC, USA, 2013.

23. EIA. Monthly Energy Review, September 2013; US Energy Information Administration: Washington, DC, USA, 2013.

24. Wallander, S.; Claassen, R.; Nickerson, C. The Ethanol Decade: An Expansion of U.S. Corn Production, 2000-09. Available online: http://www.ers.usda.gov/publications/eib-economicinformation-bulletin/eib79.aspx (accessed on 8 January 2015).

25. Roberts, M.J.; Schlenker, W. Identifying supply and demand elasticities of agricultural commodities: Implications for the US ethanol mandate. Am. Econ. Rev. 2013, 103, 2265-2295.

26. Bowyer, C. Anticipated Indirect Land Use Change Associated with Expanded Use of Biofuels and Bioliquids in the EU; Institute for European Environmental Policy: London, UK, 2010. 
27. Hertel, T.W.; Ramankutty, N.; Baldos, U.L.C. Global market integration increases likelihood that a future African Green Revolution could increase crop land use and $\mathrm{CO}_{2}$ emissions. Proc. Natl. Acad. Sci. USA 2014, 111, 13799-13804.

28. Porter, J.R.; Xie, L.; Challinor, A.J.; Cochrane, K.; Howden, S.M.; Iqbal, M.M.; Lobell, D.B.; Travasso, M.J. Food Security and Food Production Systems. In Climate Change 2014: Impacts, Adaptation and Vulnerability. Part A: Global and Sectoral Aspects; Contribution of Working Group II to the Fifth Assessment Report of the Intergovernmental Panel on Climate Change; Field, C.B., Barros, V.R., Dokken, D.J., Mach, K.J., Mastandrea, M.D., Bilir, T.E., Chatterjee, M., Ebis, K.L., Estrada, Y.O., Genova, R.C., et al., Eds.; Cambridge University Press: Cambridge, UK; New York, NY, USA, 2014.

29. Intergovernmental Panel on Climate Change (IPCC). Climate Change 2014: Impacts, Adaptation, and Vulnerability. Part A: Global and Sectoral Aspects; Contribution of Working Group II to the Fifth Assessment Report of the Intergovernmental Panel on Climate Change; Field, C.B., Barros, V.R., Dokken, D.J., Mach, K.J., Mastandrea, M.D., Bilir, T.E., Chatterjee, M., Ebis, K.L., Estrada, Y.O., Genova, R.C., et al., Eds.; Cambridge University Press: Cambridge, UK; New York, NY, USA, 2014.

30. Lal, R. Climate-strategic agriculture and the water-soil-waste nexus. J. Plant Nutr. Soil Sci. 2013, 176, 479-493.

31. Pingali, P.L. Green Revolution: Impacts, limits and the path ahead. Proc. Natl. Acad. Sci. USA 2012, 109, 12302-12308.

32. Bindraban, P.S.; van der Velde, M.; Ye, L.; van den Berg, M.; Materechera, S.; Kiba, D.I.; Tamene, L.; Ragnarsdóttir, K.V.; Jongschaap, R.; Hoogmoed, M.; et al. Assessing the impact of soil degradation on food production. Curr. Opin. Environ. Sustain. 2012, 4, 478-488.

33. Cassman, K.G.; Grassini, P.; van Wart, J. Crop yield potential, yield trends, and global food security in a changing climate. In Handbook of Climate Change and Agroecosystems; Impacts, Adaptation, and Mitigation; Hillel, D., Rosenzweig, C., Eds.; Imperial College Press: London, UK, 2011.

34. Sinclair, T.R. Precipitation: The thousand-pound gorilla in crop response to climate change. In Handbook of Climate Change and Agroecosystems; Impacts, Adaptation, and Mitigation; Hillel, D., Rosenzweig, C., Eds.; Imperial College Press: London, UK, 2011.

35. Davis, D.R. Declining fruit and vegetable nutrient composition: What is the evidence. HortScience 2009, 44, 15-19.

36. Lobell, D.B.; Roberts, M.J.; Schlenker, W.; Braun, N.; Little, B.B.; Rejesus, R.M.; Hammer, G.L. Greater sensitivity to drought accompanies maize yield increase in the U.S. Midwest. Science 2014, 344, 516-519.

37. Lambin, E.F.; Meyfroidt, P. Global land use change, economic globalization, and the looming land scarcity. Proc. Natl. Acad. Sci. USA 2011, 108, 3465-3472.

38. Quasem, M.A. Conversion of agricultural land to non-agricultural uses in Bangladesh: Extent and determinants. Bangladesh Dev. Stud. 2011, 34, 59-85.

39. Agus, F.; Irawan. Agricultural land conversion as a threat to food security and environmental quality. Indones. J. Agric. Sci. 2006, 25, 90-98. 
40. Foreign Agriculture Service. Table 09 Rice Area, Yield, Production. Available online: http://apps.fas.usda.gov/psdonline/psdReport.aspx?hidReportRetrievalName=Table+09+Rice + Are $\mathrm{a} \% 2 \mathrm{c}+$ Yield $\% 2 \mathrm{c}+$ and + Production $+\&$ hidReportRetrievalID=893\&hidReportRetrievalTemplateID=1 (accessed on 17 October 2014).

41. American Farmland Trust. National Statistics Sheet. Available online: http://www.farmlandinfo.org/ agricultural_statistics/ (accessed on 20 September 2014).

42. Nelson, G.C.; Valin, H.; Sands, R.D.; Havlik, P.; Ahammad, H.; Deryng, D.; Elliott, J.; Fujimori, S.; Hasegawa, T.; Heyhoe, E.; et al. Climate change effects on agriculture: Economic responses to biophysical shocks. Proc. Natl. Acad. Sci. USA 2014, 9, 3274-3279.

43. Godfray, H.C.H.; Beddington, J.R.; Crute, I.R.; Haddad, L.; Lawrence, D.; Muir, J.F.; Pretty, J.; Robinson, S.; Thomas, S.M.; Camilla, T. Food security: The challenge of feeding 9 billion people. Science 2010, 327, 812-818.

44. Lagi, M.; Bertrand, K.; Bar-Yam, Y. The Food Crises and Political Instability in North Africa and the Middle East. Available online: http://arxiv.org/abs/1108.2455 (accessed on 8 January 2015).

45. Lagi, M.; Bar-Yam, Y.; Bertrand, K.Z.; Bar-Yam, Y. The Food Crises: A Quantitative Model of Food Prices Including Speculators and Ethanol Conversion. Available online: http://arxiv.org/abs/ 2011 arXiv1109.4859L (accessed on 8 January 2015).

46. Piesse, J.; Thirtle, C. Three bubbles and a panic: An explanatory review of recent food commodity price events. Food Policy 2009, 34, 119-129.

47. World Meteorological Organization and Global Atmosphere Watch. The State of Greenhouse Gases in the Atmosphere Based on Global Observations through 2013. Available online: http:/www.indiaenvironmentportal.org.in/content/399916/the-state-of-greenhouse-gases-in-theatmosphere-based-on-global-observations-through-2013/ (accessed on 8 January 2015).

48. Schewe, J.; Heinke, J.; Gerten, D.; Haddeland, I.; Arnell, N.W.; Clark, D.B.; Dankers, R.; Eisner, S.; Fekete, B.M.; Colon-Gonzalez, F.J.; et al. Multimodel Assessment of water scarcity under climate change. Proc. Natl. Acad. Sci. USA 2014, 111, 3245-3250.

49. Piontek, F.; Muller, C.; Pugh, T.A.M.; Clark, D.B.; Deryng, D.; Elliott, J.; de Jesus Colon-Gonzalez, F.; Florke, M.; Folberth, C.; Franssen, W.; et al. Multisectoral climate impact hotspots in a warming world. Proc. Natl. Acad. Sci. USA 2014, 111, 3233-3238.

50. Rosenzweig, C.; Elliott, J.; Deryng, D.; Ruane, A.C.; Muller, C.; Arneth, A.; Boote, K.C.; Folberth, C.; Glotter, M.; Khabarov, N.; et al. Assessing agricultural risks of climate change in the 21 st Century in a global gridded crop model intercomparison. Proc. Natl. Acad. Sci. USA 2014, 111, 3268-3273.

51. Elliott, J.; Deryng, D.; Muller, C.; Freier, K.; Konzmann, M.; Gerten, D.; Glotter, M.; Florke, M.; Wada, Y.; Best, N.; et al. Constraints and potentials of future irrigation water availability on agricultural production under climate change. Proc. Natl. Acad. Sci. USA 2014, 111, 3239-3244.

52. Lobell, D.B.; Schlenker, W.S.; Costa-Roberts, J. Climate trends and global crop production since 1980. Science 2011, 333, 616-620.

53. Wheeler, T.; von Braun, J. Climate change impacts on global food security. Science 2013, 341, 508-513.

54. Held, I.M.; Soden, B.J. Robust responses of the hydrological cycle to global warming. J. Clim. 2006, 19, 5686-5699. 
55. Chou, C.; Neelin, J.D.; Chen, C.-A.; Tu, J.-Y. Evaluating the Rich-Get-Richer mechanism in tropical precipitation change under global warming. J. Clim. 2009, 22, 1982-2005.

56. Durack, P.J.; Wijffels, S.E.; Matear, R.J. Ocean salinities reveal strong global water cycle intensification during 1950 to 2000. Science 2012, 336, 455-458.

57. Min, S.; Zhang, X.; Zwiers, F.; Hegerl, G. Human contribution to more-intense precipitation extremes. Nature 2011, 470, 378-381.

58. Tisdall, J.M.; Oades, J.M. Organic matter and water-stable aggregates in soils. J. Soil Sci. 1982, 33, 141-163.

59. Nearing, M.A.; Pruski, F.F.; O’Neal, M.R. Expected climate change impacts on soil erosion rates: A review. Soil Water Conserv. J. 2004, 59, 43-50.

60. Fischer, G.; van Velthuizen, H.; Shah, M.; Nachtergaele, F. Global Agro-ecological Assessment for Agriculture in the 21st Century: Methodology and Results; International Institute for Applied Systems Analysis at the FAO: Rome, Italy, 2002.

61. Liu, X.; Burras, C.L.; Kravchenko, Y.S.; Duran, A.; Huffman, T.; Morras, H.; Studdert, G.; Zhang, X.; Cruse, R.M.; Yuan, X. Overview of Mollisols in the world: Distribution, land use and management. Can. J. Soil Sci. 2012, 92, 383-402.

62. IPCC. Climate Change 2007: The Physical Science Basis; Contribution of Working Group I to the Fourth Assessment Report of the Intergovernmental Panel on Climate Change; Solomon, S., Qin, D., Manning, M., Chen, Z., Marquis, M., Averyt, K.B., Tignor, M., Miller, H.L., Eds.; Cambridge University Press: Cambridge, UK; New York, NY, USA, 2007.

63. European Environment Agency. Mean Surface Temperature in Europe 1850-2009, Annual and by Season. Available online: http://www.eea.europa.eu/data-and-maps/figures/mean-surfacetemperature-in-europe (accessed 9 October 2014).

64. Turral, H.; Burke, J.; Faures, J.-M. Climate Change, Water and Food Security; FAO: Rome, Italy, 2011.

65. Ruane, J.; Sonnino, A.; Steduto, P.; Deane, C. Coping with water scarcity: What role for biotechnologies? In Climate Change, Water and Food Security; Turral, H., Burke, J., Faures, J.-M., Eds.; FAO: Rome, Italy, 2011.

66. Konikow, L.F. Groundwater Depletion in the United States (1900-2008). Available online: http://pubs.usgs.gov/sir/2013/5079/SIR2013-5079.pdf (accessed on 20 October 2014).

67. Currell, M.J.; Han, D.; Chen, Z.; Cartwright, I. Sustainability of groundwater usage in northern China: Dependence on palaeowaters and effects on water quality, quantity and ecosystem health. Hydrol. Process. 2012, 26, 4050-4066.

68. Brown, L.; Black, B.; Hussein, G.H.G. Aquifer depletion. In Encyclopedia of Earth; Cleveland, C.J., Ed.; Environmental Information Coalition, National Council for Science and the Environment: Washington, DC, USA, 2011.

69. Konikow, L.F. Contribution of global groundwater depletion since 1900 to sea-level rise. Geophys. Res. Lett. 2011, doi:10.1029/2011GL048604.

(C) 2015 by the authors; licensee MDPI, Basel, Switzerland. This article is an open access article distributed under the terms and conditions of the Creative Commons Attribution license (http://creativecommons.org/licenses/by/4.0/). 